\title{
First description of the males of Aphelenchoides limberi Steiner, 1936 (Nematoda: Aphelenchina)
}

\author{
V. ČERMÁK ${ }^{1}$, L. HÁNĚL ${ }^{2}$, V. GAAR ${ }^{1}$, O. DOUDA ${ }^{3}$ \\ ${ }^{1}$ State Phytosanitary Administration, Division of Diagnostics, Šlechtitelů 773/23, 77900 Olomouc, Czech Republic; \\ ${ }^{2}$ Biology Centre, Academy of Science of the Czech Republic, v.v.i., Institute of Soil Biology, Na Sádkách 7 , \\ 37005 České Budějovice, Czech Republic; ${ }^{3}$ Crop Research Institute, Drnovská 507, 16106 Praha 6 - Ruzyně, \\ Czech Republic
}

\begin{abstract}
Summary
Males of Aphelenchoides limberi are described and illustrated for the first time from mushroom plate cultures of Botrytis cinerea. The original parthenogenetic population was extracted from the soil of a hop garden in Senice na Hané, Czech Republic. The males are characterized by a stylet about $11 \mu \mathrm{m}$ long, a prominent spicula, with the dorsal limb longer than the ventral limb, and a ventrally curved tip. The tail is arcuate, conoid, ending with a short, mostly ventrally bent hook-shaped mucro, the lateral field appears to have four lines under light microscopy.
\end{abstract}

Keywords: nematode; parthenogenesis; amphimixis; morphology; males; fungal cultures

\section{Introduction}

Aphelenenchoides belongs to the richest genera of freeliving nematodes. Currently, 181 species are recognized; 47 species have been observed in Europe to date (Andrássy, 2007). Members of the genus Aphelenchoides are predominantly free-living and are found world-wide in soil, decaying plant material, galleries of wood-boring beetles, marine littoral regions etc., probably leading a fungivorous lifestyle (Hunt, 1993; Yeates et al., 1993).

Aphelenchoides limberi Steiner 1936 was first described in 1936 in Iris tingtiana bulbs that originated from the Netherlands (Steiner, 1936). Later it was found also in leaves of Dahlia sp. originating from Germany and in the roots of elms imported from California USA (Steiner, 1938); parasitism of cotton roots in Hungary was described as well (Andrássy, 1954, 1972, 1990). Today, Aphelenchoides limberi is broadly spread throughout Europe (e.g. Hooper, 1962; Sabová et al., 1978; Peña-Santiago et al., 2006) and the Asian part of Russia (e.g. Tulaganov, 1972; Baranovskaya, 1981). Outside of Europe it was found also in Canada (Sewell, 1973), Africa - Ivory Coast (Merny,
1970), Cuba and Australia (Andrássy, 2007). In the Czech Republic the species was mainly found in loamy agricultural soils (authors' unpublished data).

Its bionomics is not well known. According to Hooper (1962), A. limberi could act as a fungal feeder, and its reproduction is parthenogenetic. So far, males were reported only once by Andrássy (1954) from Hungary without related morphological and morphometrical data. This is the first study describing $A$. limberi males, obtained from a population found in a hop garden and cultivated under in vitro conditions.

\section{Materials and methods}

The original population of females and juveniles of $A$. limberi was extracted from the soil samples collected from a hop garden near the village of Senice na Hané, Czech Republic in August 2007. GPS: N49 37.192, E17 06.611 (256 $\mathrm{m}$ a.s.1.)

Extraction of nematodes was done from soil by Cobb's flotation-sieving method (Cobb, 1918). Extracted nematodes were killed and fixed by hot $4 \%$ formaldehyde and transferred to glycerin according the De Grisse (1969) and identified under a light microscope. Ten extracted living females were transferred and washed in sterile water three times and then put into a small drop of sterile water on each culture of Botrytis cinerea Pers. ex Fr. in Petri dishes. Ten adult females were inoculated per one Petri dish. Total the eight Petri dishes were inoculated and incubated at $26{ }^{\circ} \mathrm{C}$ for three weeks in an incubator, then checked under a light microscope and re-cultured on the new Petri dishes. The counts were made five times (Table1). Each count contained eight mushroom plates. Only females and males were counted, juveniles were excluded. Measurements are given in $\mu \mathrm{m}$. Photos of males and females and drawings and measurements were made of specimens mounted in 
Table 1. Morphometric data for males Aphelenchoides limberi $[\mu \mathrm{m}]$

\begin{tabular}{|c|c|c|c|c|}
\hline & $\begin{array}{c}\text { Males } \\
\text { mean } \pm \text { s.d. }\end{array}$ & range & $\begin{array}{c}\text { Females } \\
\text { mean } \pm \text { s.d. }\end{array}$ & range \\
\hline $\mathrm{n}$ & 11 & & 24 & \\
\hline $\mathrm{L}$ & $643.5 \pm 51.0$ & $(540-702)$ & $740.0 \pm 78.6$ & $(639-960)$ \\
\hline $\mathrm{a}$ & $32.9 \pm 3.9$ & $(28.3-39.7)$ & $33.1 \pm 2.7$ & $(29.1-42.4)$ \\
\hline $\mathrm{b}$ & $10.5 \pm 0.8$ & $(9.0-11.6)$ & $10.4 \pm 0.9$ & $(9.0-12.2)$ \\
\hline$b^{\prime}$ & $4.6 \pm 0.3$ & $(4.0-5.1)$ & $4.8 \pm 0.4$ & $(4.3-5.9)$ \\
\hline $\mathrm{c}$ & $16.9 \pm 1.2$ & $(15.0-18.6)$ & $18.1 \pm 1.4$ & $(16.5-22.2)$ \\
\hline $\mathrm{c}^{\prime}$ & $2.2 \pm 0.3$ & $(1.7-2.6)$ & $3.3 \pm 0.3$ & $(2.9-3.9)$ \\
\hline $\mathrm{V}$ & - & - & $69.3 \pm 1.3$ & $(66.3-71.8)$ \\
\hline MB & $87.6 \pm 2.7$ & $(85.1-93.9)$ & $83.7 \pm 3.0$ & $(74.1-83.0)$ \\
\hline $\begin{array}{l}\text { Anterior end to valves } \\
\text { of median bulb }\end{array}$ & $53.8 \pm 4.8$ & $(47.9-64.3)$ & $59.3 \pm 3.1$ & $(54.4-66.8)$ \\
\hline Oesophagus length & $61.3 \pm 4.0$ & $(56.3-68.3)$ & $71.3 \pm 4.9$ & $(62.2-83.0)$ \\
\hline Stylet length & $11.3 \pm 0.2$ & $(11.2-11.9)$ & $12.2 \pm 0.7$ & $(10.6-13.7)$ \\
\hline Head width & $5.5 \pm 0.3$ & $(5.0-6.3)$ & $6.7 \pm 0.4$ & $(6.0-7.2)$ \\
\hline Head height & $2.8 \pm 0.2$ & $(2.6-3.1)$ & $3.1 \pm 0.3$ & $(2.3-3.6)$ \\
\hline Tail length & $38.3 \pm 3.0$ & $(34.3-45.0)$ & $40.9 \pm 3.7$ & $(34.1-47.1)$ \\
\hline Cloacal/anal width & $14.4 \pm 2.0$ & $(11.4-17.4)$ & $12.3 \pm 1.4$ & $(10.5-16.2)$ \\
\hline Body width & $20.0 \pm 3.4$ & $(13.6-24.4)$ & $22.5 \pm 2.8$ & $(18.4-32.1)$ \\
\hline PUS & - & - & $83.2 \pm 13.3$ & $(63.3-123.7)$ \\
\hline Spicula - DL & $32.2 \pm 1.7$ & $(30.0-35.2)$ & - & - \\
\hline Spicula - VL & $16.7 \pm 0.6$ & $(15.4-17.6)$ & - & - \\
\hline
\end{tabular}

glycerine in permanent slides. Permanent slides have been deposited in the collection of State Phytosanitary Administration, Department of Nematology, Olomouc.

\section{Results}

\section{Measurements and description}

A total of 13 males and several thousand females were developed in mushroom plates of Botrytis cinerea. Morphological data of males (11) and females (24) of Aphelenchoides limberi are given in Table 1.

The body of males is slender; the anterior part of the body is slightly curved and ventrally bent. After gentle heat treatment, the hook like tail becomes dorsally convex, medium conoid, the terminus ventrally mucronate. The Mucro is short, conoid, more or less bent ventrally. The cuticle has fine transverse annulations (about $1 \mu \mathrm{m}$ ) interrupted by a lateral field with four lines. Males are on average shorter than females. The lip region is anteriorly flattened, slightly set-off, with rounded sides. The Stylet is $11.2-11.9 \mu \mathrm{m}$ long, with distinct thickenings at the base. The shape of the medial bulb is rounded to slightly oval with centrally to slightly posteriorly placed distinct valves. The excretory pore is located ventrally opposite to and slightly posterior to the nerve ring. The testes are single, outstretched or anteriorly folded or reflexed.

The reproductive system occasionally reaches the pharynx. Developing germ cells are set anteriorly in double file and more posteriorly in single file. The Spicule is typically aphelenchoid, strongly arcuate. The apex is extended, moderately developed, and rounded. The rostrum is short, rounded or slightly pointed. A tangent drawn from the apex to the rostrum usually passes through the tip of the spicules. The lamina is well developed. The dorsal limb of spicule is longer than ventral limb (with a difference of around $3 \mu \mathrm{m}$ ), smoothly curved in its proximal half but more or less concave in the distal half with a ventrally curved tip. There is no gubernaculum. The tail is arcuate, conoid, ending with a short mostly ventrally bent, hook shaped mucro (around $1.2 \mu \mathrm{m}$ ) (Fig. 1, 2). Three pairs of caudal papillae are present (observed with light microscopy), one pair adanal, placed subventrally; the second pair subventral is at about $50 \%$ of the distance to the tail tip, and the third pair placed ventrally close to the tail tip. 


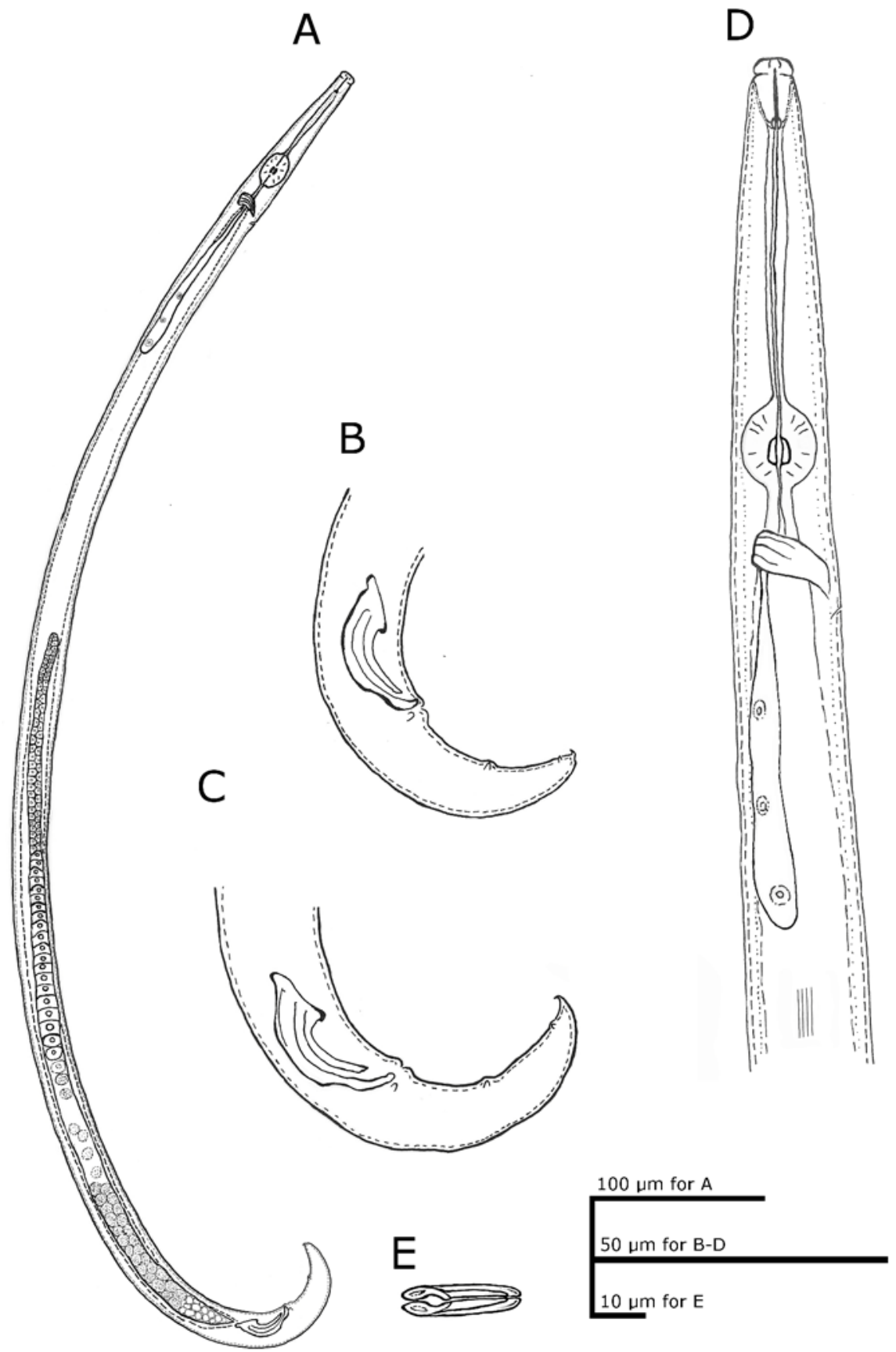

Fig. 1. Aphelenchoides limberi. A - male; B, C - male tail; D - head region; E - spicula - ventral view

\section{Diagnoses and relationships}

The Male of Aphelenchoides limberi is characterized by a stylet about $11 \mu \mathrm{m}$ long, a prominent spicule, with an extended, moderately developed and rounded apex. A tangent drawn from the apex to the rostrum usually passes through the tip of the spicule. It is smoothly curved in its proximal half but more or less concave in the distal half, with a ventrally curved tip. Thetail is arcuate, conoid, ending with a short mostly ventrally bend - the hamate mucro. The lateral field appears to have four lines under light microscopy.

Aphelenchoides limberi belongs to Group 1 according to Shanina (1996), because the female tail has no outgrowth or mucronate structure. However, Hooper (1962) reported high variability among female tails, and described very short central mucro on the end of the tail. Female tails also show high variability in our cultured population (Fig. 2). The shape of the tail tip varied from truncate to smoothly rounded. The mucronate tail occurred very occasionally. The only two species from Group 1 with males with mucronate tail are A. africanus, Danssonville \& Heyns, (1984) and $A$. spinosus Paesler, (1957). The males of $A$. limberi differ from the males of of the A. africanus species mainly by the length of mucro (3.25 vs. $15 \%$ of tail length), the number of lateral lines (two vs. four) They 

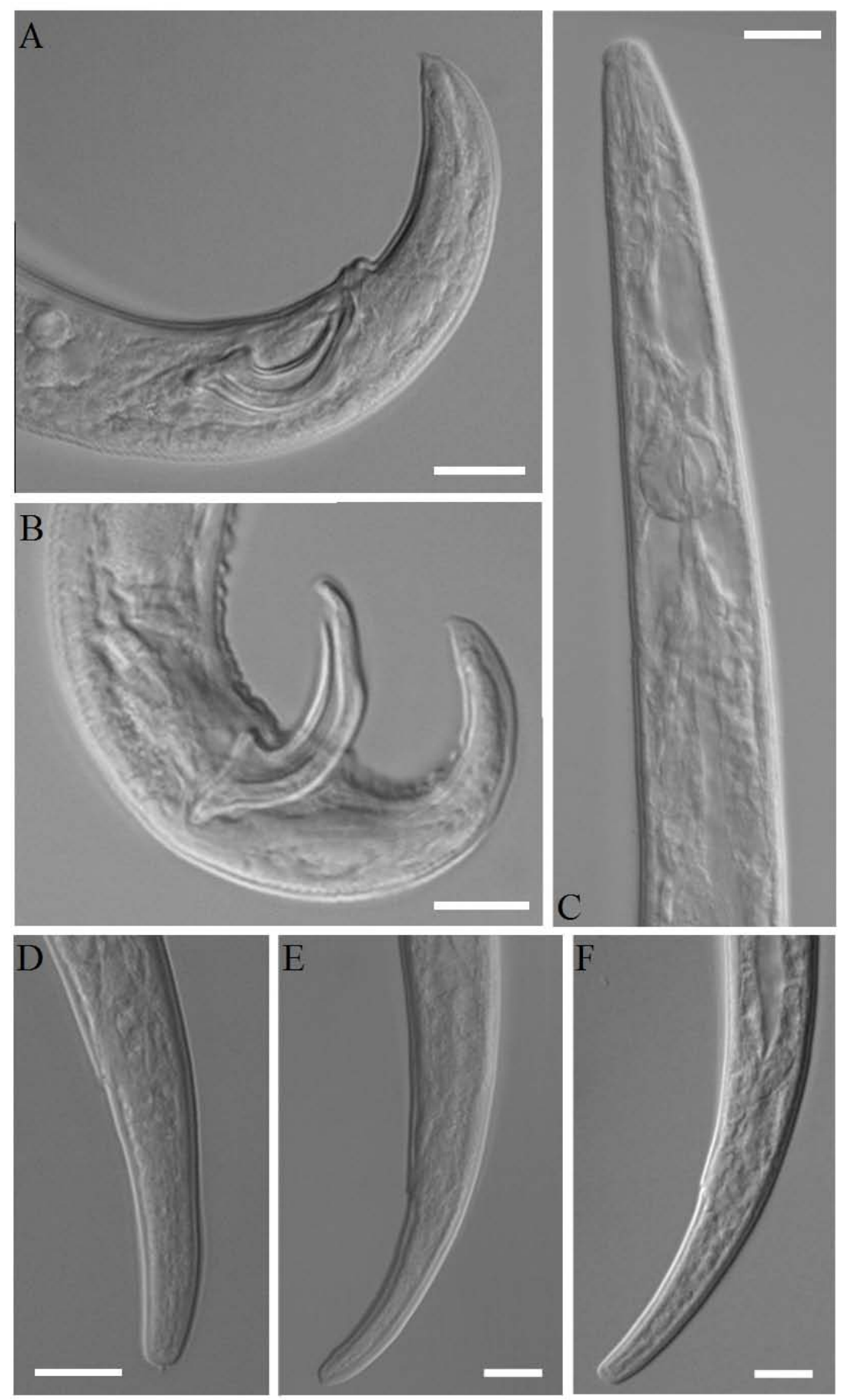

Fig. 2. Aphelenchoides limberi. A, B: Male tail; C: Head region; D, E, F: Female tail. Scale bar - $10 \mu \mathrm{m}$

differ from males of $A$. spinosus mainly by body length $(0.37-0.48$ vs. $0.54-0.72 \mathrm{~mm})$ and the shape of the mucro. Males of $A$. limberi are close to A. brassicae Edward \& Mistra, 1969, A. cyrtus Paesler, 1957, A. haguei Maslen, 1979, A. paranechaelos Hooper \& Ibrahim, 1994, A. parasaprophilus Sanwal, 1965, A. tsalolikhini Ryss, 1993 and A.tumulicaudatus Truskova, 1973 by the combinations of stylet, body length and number of lateral lines. Males of $A$. limberi differ from males of $A$. brassicae and $A$. cyrtus by longer spicula, differently shaped and shorter tail tip mucro and by slightly greater body length. $A$. haguei has different spicula and mucro shape (straight and minutely multi-papillate). The average length of the spicula and stylet of $A$. paranechaelos is shorter and has a higher $\mathrm{c}^{\prime}$ (3.1 vs. 2.2). It differs from $A$. parasaprophilus by a shorter and differently shaped mucro and shorter stylet length on average. A. tsalolikhini has a longer mucro (6.4 vs. $1.2 \mu \mathrm{m})$ and shorter spicula $(18-19$ vs. $30.0-35.2 \mu \mathrm{m})$. Males of A. tumulicaudatus have a differently shaped mucro, and a double concave dorsal limb of the spicula. 


\section{Discussion and conclusion}

Aphelenchoides limberi is a common cosmopolitan fungivorous species (Hooper, 1962; Andrássy, 2007) inhabiting mainly loamy soils. According to original descriptions from the Netherlands in lesions on a dahlia tubers which originated form from Germany (Steiner, 1936), and in the elm roots from California (Steiner, 1939), only females were recorded. Males were noted only once in Hungary (Andrássy, 1954). Andrássy (1954) found only two males associated with the cotton roots and unfortunately he did not provide any description. Our described males of $A$. limberi originated from the parthenogenetic population extracted from the loamy soil of a hop garden. Extracted females were successfully grown on the fungi Bothritis cinerea, which positively corresponds with the findings of Hooper (1962), who found them feeding and developing on mushroom mycelium (Agaricus hortensis and Botrytis cinerea). In spite of rapid reproductive rate of A. limberi only females were developed (Hooper, 1962). However, our examined population of $A$. limberi originated from females extracted from soil and grown on fungi $B$. cinerea produced a low number of males in the initial population. No males were recorded on the consequent (reinoculated) mushroom plates. In general, the cultured population of $A$. limberi reproduced without males, which positively corresponds with the observations of Hooper (1962). The reason for the occasional occurrence of males could be changes in life conditions (Evans \& Fisher, 1970), the food web (Riddle et al., 1997), temperature (Hansen et al., 1970 and 1972) or infection by intracellular parasitic microorganisms (Hurst, 1993; Stevens et al., 2001).

\section{Acknowledgements}

We would like to thank to Kateřina Široká, State Phytosanitary Administration, for technical support and to anonymous reviewers for their comments. The study was carried out as a part of the IRP ISB BC AS CR AV0Z60660521 (L. Háněl).

\section{References}

ANDRÁSSY, I. (2007): Free-living Nematodes of Hungary (Nematoda Errantia), Volume II. Hungarian Natural History Museum and Systematic Zoology Research Group of the Hungarian Academy of Sciences, Budapest, 496 pp. ANDRÁSSY, I. (1954): Parasitische Nematoden aus der Wurzel der Baumwolle. Ann. biol. Univ. Hung., 2: 3 - 7 ANDRÁSSY, I. (1972): List of free-living Nematoda detected in Hungary. Állatt. Közlem., 59: 161 - 171 (In Hungarian) ANDRÁSSY, I. (1990): Free-living Nematoda in the Hungarian fauna. Állatt. Közlem., 76: 17 - 38 (In Hungarian) BARANOVSKAYA, I. A. (1981): Plant and soil nematodes (aphelenchids and seinurids). Moscow, pp. 233 (In Russian) CoBB, N. A. (1918). Estimating the nema population of the soil. Agric. Tech. Circ. Bur. Pl. Ind. U.S. Dep. Agric, 1: 48 pp. DE Grisse, A. (1969). Redescription ou modi. cations de quelques techniques utilisées dans l'étude des nématodes phytoparasitaires. Mededelingen Rijksfaculteit der Landbouwwetenschappen Gent, 34: 351 - 369

EvAns, A. A. F., FISHER, J. M. (1970): Differences between four Australian isolates of Aphelenchus avenae Bastian. Aust. J. Biol. Sci., 23: 507 - 509

Hansen, E. L., Buecher, E. J., Evans, A. A. F. (1970): Axenic culture of Aphelenchus avenae. Nematologica, 16: $328-329$

Hansen, E. L., Yarwood, E. A., Buecher, E. J. (1972): Sex differentiation of Aphelenchus avenae in axenic culture. Nematologica, 18: $253-260$

HOOPER, D. J. (1962): Observations on Aphelenchoides limberi Steiner, 1936, from mushroom compost. Nematologica, 7: 216 - 218

HunT, D. J. (1993): Aphelenchida. Longidoridae and Trichodoridae - Their Systematics and Bionomics, UK, CABI Publishing, 352 pp.

HURST, L. D. (1993): The incidences, mechanisms an evolution of cytoplasmic sex ratio distorters in animals. Biol. Rev., 6: 121 - 194. DOI: 10.1111/j.1469-185X.1993.tb00733.x

KheIrI, A., BArooti, S., Karimipour, H. (2002): Tylenchida associated with field crops in Tehran and central provinces of Iran. Meded. Rijksuniv. Gent Fak. Landbouwkd. Toegep. Biol. Wet., 67: 707 - 713

MERNY, G. (1970): Les Nématodes phytoparasites des rizièrws inondées en Cote D'Ivoire - I. - Les Espèces observes. Sér. Biol, Cah. Orstom, 11: $3-43$

NIKISHICHEVA, K. S. (2002): Fauna of plant parasitic nematodes of winter wheat in different climatic zones of Ukraine. Vestnik zoologii, 36: 95 - 97 (In Russian)

Peña-Santiago, R., Abolafia, J., Guerrero, P., LiÉbanas, G., Peralta, M. (2006): Soil and Freshwater Nematodes of the Iberian Fauna: a Synthesis. Graellsia, 62: $179-198$

RIDDle, D. L., Albert, P. S. (1997): Genetic and environmental regulation of dauer larva development. In: Riddle, L. D., Blumenthal, T., Meyer, B. J., Priess, J. R. (Eds) C. elegans II. New York: Cold Spring Harbor Laboratory Press, pp. $739-768$

SABOVÁ, M., VALOCKÁ, B., LiŠKOVÁ, M. (1978): Species of corn crop nematodes and their seasonal dynamics. Helminthologia, 16: $35-44$

SEWELL R. (1973): Plant-parasitic Nematodes from Canada and abroad. Can. Plant Dis. Surv., 1: $34-35$

SHANINA, F. (1996): A diagnostic compendium of the genus Aphelenchoides Fisher, 1894 (Nematoda: Aphelenchida) with some new records of the group from Pakistan. Pak. J. Nematol., 14: 1 - 32

STEINER, G. (1936): Observations on Nematodes in Bulbs of an Iris tinginata Hybrid. Opuscula miscellanea nematologica IV, Proc. Helminth. Soc. Wash., 3: $74-77$

STEINER, G. (1938): Futher notes on Aphelenchoides limberi (Stainer, 1936). Opuscula miscellanea nematologica, VII, Proc. Helminth. Soc. Wash., 7: $35-40$

SteVens, L., Giodano, R., FialHo, F. R. (2001): Male-killing, nematode infections, bacteriophage infection, and virulence of cytoplasmic bacteria in the genus Wolbachia. Annu. 
Rev. Ecol. Syst., 32(5): 519 - 545. DOI: 10.2307/2678650

Tulaganov, A. T. (1972): Plant parasitic and soil freeliving nematodes of Uzbekistan. Tashkent, SSSR, $356 \mathrm{pp}$. (In Russian)

RECEIVED DECEMBER 22, 2011
Yeates, W. G., Bongers, T., Goede, R. M. G., FreCKMAN, D. W., Georgieva, S. S. (1993): Feeding habits in soil nematode families and genera - an outline for soil ecologists. J. Nematol., 25: $315-331$

ACCEPTED APRIL 18, 2012 